\title{
Morphological and Molecular Characterization of Xiphinema krugi from Argentina Associated with Silk Floss Tree (Ceiba speciosa) Intercepted in China
}

\author{
Eda Marie Barsalote', Zhongling Tian', Fangrong $\mathrm{Li}^{\mathbf{3}}$ and Jingwu Zheng ${ }^{\mathbf{1 , 2 *}}$ \\ ${ }^{1}$ Institute of Biotechnology, College of Agriculture and Biotechnology, Zhejiang University, Hangzhou 310058, China \\ ${ }^{2}$ Ministry of Agriculture Key Lab of Molecular Biology of Crop Pathogens and Insects, Zhejiang, Hangzhou 310058, China \\ ${ }^{3}$ Shenzhen Entry-Exit Inspection and Quarantine Bureau, Shenzhen 518045, China \\ *For correspondence: jwzheng@zju.edu.cn
}

\begin{abstract}
A population of dagger nematode from Argentina was intercepted by Quarantine Bureau in Shenzhen, China. Xiphinema sp. was recovered from imported silk floss tree (Ceiba speciosa). Morphometric studies of the intercepted Xiphinema agreed with the description of $X$. krugi from Argentina and Brazil with slight variations in morphometric values of c' $(1.1 \mu \mathrm{m}$ vs. $1.3 \mu \mathrm{m}$ vs. $1.2 \mu \mathrm{m})$, odontostyle length $(114 \mu \mathrm{m}$ vs. $112 \mu \mathrm{m}$ vs. $116 \mu \mathrm{m})$, ratio of anterior genital branch as expressed to diameter of vulva $(1.8 \mu \mathrm{m}$ vs. $1.6 \mu \mathrm{m}$ vs. $2.2 \mu \mathrm{m})$. Phylogenetic analyses of $X$. krugi (KY011940) using ITS1 rDNA region indicated a well-supported $(\mathrm{PP}=0.98)$ clade to $X$. krugi putative species from Brazil classified as genotypes profile B (DQ017149DQ017151), all these specimens shares morphologically a conoid tail and distinct ventral peg. This is the first interception report of $X$. krugi, from Argentina in China associated with Ceiba speciosa. (C) 2017 Friends Science Publishers
\end{abstract}

Keywords: Argentina; Ceiba speciosa; China; Quarantine; Xiphinema krugi

\section{Introduction}

Genus Xiphinema, known as the "dagger nematode" are ectoparasitic migratory that feds on wide range of herbaceous and woody plants which are found prevalent in all continents (Taylor and Brown, 1997). This group is economically important because of its virus vector ability resulting to phytosanitary risk of some plant species (Decraemer et al., 1998). Xiphinema krugi are reported to be widely distributed in tropical and subtropical climates (Luc and Hunt, 1978). The species is originally described in the rhizosphere of natural vegetation in Piracicaba, Sao Paulo (Maximiano et al., 1998) a pseudomonodelphic species most prevalent in Brazil (Lamberti et al., 1978; Germani, 1989; Oliveira et al., 2006) and relatively widespread in USA (Doucet et al., 1998).

$X$. krugi were also recorded in Argentina (Luc and Doucet, 1990), Paraguay (Luc and Hunt, 1978), Colombia (Volcy, 1990), Surinam (Loof and Maas, 1972), Martinique (Luc and Coomans, 1992), Uruguay (Jacob and Loof, 1996), Trinidad (Bala, 1984), Venezuela (Crozzoli et al., 2001), Senegal (Luc and Hunt, 1978) and Hongkong (Shen et al., 1999). A pantropical distribution of this species was reported by Coomans et al. (2001). The common occurrence of $X$. krugi is probably explained by its wide host range (e.g. grassland, ornamentals and natural vegetation) (Costa Manso et al., 1994). The taxonomic status of $X$. krugi has been questioned due to morphological and morphometric heterogeneity (Luc and Hunt, 1978) and was considered to be synonym of $X$. denoudeni and $X$. loosi (Loof and Maas, 1972; Southey and Luc, 1973) This is because existing a resemblance of female genital branch and tail shape. Studies by Luc and Hunt (1978) including groups with distinct populations of $X$. krugi, group one was a population previously described as $X$. loosi having a short hemispheroid tail $(29.3 \mu \mathrm{m})$ and short anterior genital branch $(60.5 \mu \mathrm{m})$, a second group was an American population with long conoid tail and distinct ventral peg, a third group including two populations one from Paraguay and the other from Surinam both populations with mean tail of $35 \mu \mathrm{m}$ and anterior genital branch of $72 \mu \mathrm{m}$, and a fourth group contained a putative population of $X$. krugi having a tail length of $31.8 \mu \mathrm{m}$ and long anterior genital branch of $97.5 \mu \mathrm{m}$ (Lordello, 1955).

In this study, a population of Xiphinema sp. was recovered from soils around the roots of silk floss tree (Ceiba speciosa) imports from Argentina intercepted by Shenzhen Entry-Exit Inspection and Quarantine Bureau. Studies of the intercepted Xiphinema sp. were conducted using a combination of morphology and molecular approach. Characterization of diagnostic characters for Xiphinema krugi and nucleotide sequences of ITS1 and 28S region of rDNA were used to compare to the intercepted Xiphinema and are presented in this paper. 


\section{Materials and Methods}

\section{Morphological Identification}

Samples of Xiphinema sp. used in this study were isolated and collected from soil and rhizosphere of silk floss tree imported from Argentina. Nematodes were extracted using modified method of Cobb's decanting and sieving (Brown and Boag, 1988). Nematodes were handpicked from the suspension. Killed over the flame for further ocular inspection, and for photographic documentation. Twelve adult females were kept for fixation and for preparation of permanent slides (Ye et al., 2004). Photomicrographs were obtained using Zeiss compound microscope (Stem 2000-C) with attached digital camera. Morphometric were carried out using an installed software from Zeiss. All morphometric values are in $\mu \mathrm{m}$ and are expressed as mean $\pm \mathrm{SD}$.

\section{Molecular Characterization}

Extraction of DNA was made using a single adult nematode. The nematode was placed to temporary glass slide

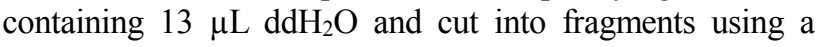
scalpel pre-heated over the flame. Fragments of nematode were pipetted up to $10 \mu \mathrm{L}$ and transferred to Eppendorf tube and added with $8 \mu \mathrm{L} \mathrm{Mg}+$ free buffer and $2 \mu \mathrm{L}$ proteinase $\mathrm{K}$ (Ye et al., 2004). DNA extracts were centrifuged at 12000 rpm for $2 \mathrm{~min}$ and overnight stored at minus $70^{\circ} \mathrm{C}$. The following day, each Eppendorf tube was incubated in a PCR machine using the following thermal protocol $65^{\circ} \mathrm{C}$ for $3 \mathrm{~h}$, $75^{\circ} \mathrm{C}$ for $60 \mathrm{~min}$ and $95^{\circ} \mathrm{C}$ for 10 minutes. Afterwards, DNA suspensions were cooled down at $8^{\circ} \mathrm{C}$ and stored at minus $20^{\circ} \mathrm{C}$ until further use. A volume of $25 \mu \mathrm{L}$ PCR mix consisting $2.5 \mu \mathrm{L}$ LA buffer, $2 \mu \mathrm{L}$ dNTP, $1.5 \mu \mathrm{L}$ each primers (synthesized by Takara Company, Shanghai, China) and $3 \mu \mathrm{L}$ DNA templates, $0.3 \mu \mathrm{L}$ LATaq and $14.2 \mu \mathrm{L}$ distilled water. All PCR reactions were conducted in the S1000 thermal cycler (BIO-RAD).

Generations of PCR products were conducted as previous described (Oliveira et al., 2004). Fragments of ITS1 and $28 \mathrm{~S}$ region were amplified using two sets of primers. First set: forward primer V1 (5'-TTG ATT ACG TCC CTG CCC TTT-3') and reverse primer 5.8S (5'-ACG AGC CGA GTG ATC CAC CG-3') (Gutierrez et al., 2010) and, the second set: forward primer D2A (5' ACA AGT ACC GTG AGG GAA AGT TG 3') and reverse primer D3B (5' TCG GAA GGA ACC AGC TAC TA 3') (De Ley et al., 1999), After DNA amplification, $2.5 \mu \mathrm{L}$ aliquots of PCR products were analyzed by gel electrophoresis in $1 \%$ agarose gel (100V, $400 \mathrm{~mA}, 30$ minutes) stained with DuRed 10,000x stain (Cat\#D009-500) and DNA were visualized under UV illumination. Amplified DNA were purified according to TaKaRa DNA fragment Purification kit version 4.0 (catalogue No. 9761) of TaKaRa Clontech Bio Inc., China. Purified DNA were ligated to pUCM-T vector and transformed in to DH 5alpha competent cells and transformants were screened on an ampicillin agar LB plates at $37^{\circ} \mathrm{C}$ overnight. White colonies were selected and transferred to $5 \mathrm{~mL} \mathrm{LB}$ containing $100 \mu \mathrm{g} \mu \mathrm{L}^{-1}$ ampicillin and incubated at $37^{\circ} \mathrm{C}$ for $16-24 \mathrm{~h}$. PCR amplification was confirmed using the primer insertion and expected band. Sequencing was done at the SANGON Biotechnology Co., Ltd. Obtained sequences were submitted to GenBank for further comparison of closely related species. Sequences were analyzed and aligned using Clustal W program (Thompson et al., 1994) of the Mega 5.0 (Tamura et al., 2011).

\section{Results}

\section{Xiphinema krugi Lordello, 1955}

Measurements and distribution see Tables 1 and 2

Female: Body appears open C-shaped upon heat relaxed (Fig. 1A). Cuticle smooth with obscure transverse body striations. Head rounded, labial region offset by slight constriction from body profile (Fig. 1B-E). Body size averaging 1.8-2.2 mm, odontostyle $(\mathrm{n}=12)$ long $(116-120$ $\mu \mathrm{m})$, odontophore flange well-developed. Vulva transverse slit (Fig. 2B) and positioned 31-34\% from anterior end (Fig. $1 \mathrm{~F}$ ) while vagina is about $40 \%$ of body width (Fig. $2 \mathrm{E}$ ). Total oesophageal length of $377 \mu \mathrm{m}$, the basal bulb of esophagus measuring $92 \mu \mathrm{m}$ long and $26.5 \mu \mathrm{m}$ wide. Reproductive system consists of two branches with anterior reduced $67 \mu \mathrm{m}(61-94 \mu \mathrm{m})$ without ovary and short uterus, while posterior branch is normally developed $234 \mu \mathrm{m}(228$ $242 \mu \mathrm{m})$ consisting of ovary, oviduct and uterus (Fig. 2A). Tail conoid rounded with a slight depression in the dorsal side at the beginning of peg (Fig. 1G-J). Ventral peg distinct to all specimens. Cuticle at tail terminus with very faint oblique lines (Fig. 2C). Caudal pores present (Fig. 2F-G).

Male: Not found

\section{Differential Diagnosis}

Xiphinema krugi can be recognized from other Xiphinema species by lack of anterior ovary. Morphologically constitute similar structure to $X$. filicaudatum, $X$. longicaudatum; $X$. surinamense and $X$. variegatum, all belonging to taxonomic group II which characterized by only developed posterior genital branch. However, $X$. filicaudatum and $X$. longicaudatum can be easily distinguished in the difference of long tails having 363-545 $\mu \mathrm{m}$ and $154-241 \mu \mathrm{m}$, respectively. $X$. krugi is closely similar to $X$. surinamense having conoid-hemispheroid tail but has much a longer anterior genital branch (240 vs. 51$93 \mu \mathrm{m})$ and apparently posterior vulva ( $\mathrm{V}=36-42$ vs. $31-34$ $\mu \mathrm{m})$. Whereas $X$. variegatum has female genital branch shorter (45-52 vs. 51-93 $\mu \mathrm{m})$ than $X$. krugi.

\section{Molecular Characterization and Phylogenetic Relationships}

The amplification product of partial D2-D3 expansion 
Table 1: Morphometric of Xiphinema krugi from Argentina intercept in China including comparisons to previous studies using populations from different origin and crops

\begin{tabular}{|c|c|c|c|c|c|c|c|c|c|}
\hline Origin Host & $\begin{array}{l}\text { In this study Silk } \\
\text { floss tree }\end{array}$ & $\begin{array}{l}\begin{array}{l}\text { Brazil } \\
\text { (Lordello, } \\
\text { 1955) Natural } \\
\text { vegetation }\end{array} \\
\end{array}$ & $\begin{array}{l}\text { Paraguay } \\
\text { (Luc \& Hunt, } \\
\text { 1978) Sugar } \\
\text { cane }\end{array}$ & 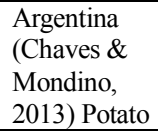 & $\begin{array}{l}\text { Surinam } \\
\text { (Loof \& } \\
\text { Mass, 1972) } \\
\text { Citrus } \\
\end{array}$ & $\begin{array}{l}\text { Senegal } \\
\text { (Luc \& } \\
\text { Hunt, 1978) } \\
\text { Citrus } \\
\end{array}$ & $\begin{array}{l}\text { USA } \\
\text { (Ye \& Robbins, } \\
\text { 2010) } \\
\text { Hardwood tree }\end{array}$ & $\begin{array}{l}\text { Hongkong } \\
\text { (Shen et al., } \\
\text { 1999) Elm } \\
\text { tree }\end{array}$ & $\begin{array}{l}\text { Sri Lanka } \\
\text { (Southey \& } \\
\text { Luc, 1973) } \\
\text { Easter Lily } \\
\end{array}$ \\
\hline & 12 & 5 & 20 & 4 & 50 & 15 & 4 & 20 & 11 \\
\hline $\mathrm{L}(\mathrm{mm})$ & $1.9 \pm 0.21(1.8-2.2)$ & $2.12-2.22$ & $2.07-2.56$ & $2.0-2.34$ & $1.93-2.41$ & $1.91-2.32$ & $1.9-2.2$ & $1.88 \pm 0.69$ & $1.78-2.18$ \\
\hline $\mathrm{a}$ & $41.2 \pm 1.8(40.5-42.5)$ & $37.9-43.8$ & $31.2-56.9$ & $42.5-50$ & $39-49$ & $49.3-59.5$ & $31.3-51.1$ & $36.9 \pm 9.2$ & $32.9-37.5$ \\
\hline $\mathrm{b}$ & $5.4 \pm 0.65(4.9-6.7)$ & $5.2-5.6$ & $4.5-6.4$ & 4.9-5.4 & $4.8-6.5$ & $4.2-5.8$ & $4.7-5.2$ & $4.8 \pm 0.3$ & - \\
\hline $\mathrm{c}$ & $64.2 \pm 5.2(63.2-72)$ & $66.3-69.6$ & $54.2-80.5$ & $52-60$ & $55-74$ & $62.6-73.1$ & $51.1-61.8$ & $64.4 \pm 4.2$ & $66-90$ \\
\hline$c^{\prime}$ & $1.1 \pm 0.11(0.9-1.1)$ & $1.2-1.4$ & $0.8-1.1$ & $1.3-1.4$ & $1.2-1.3$ & $1.0-1.2$ & $0.9-1.2$ & $0.9 \pm 0.1$ & $0.57-0.80$ \\
\hline $\mathrm{V}$ & $32.8 \pm 1.3(31.8-34)$ & $33.4-34.2$ & $33.6-35.9$ & $33-35$ & $32-36$ & 31.9-35.9 & $33.5-36.1$ & $33.28 \pm 1.2$ & $28.6-33.3$ \\
\hline Odontostyle & $114 \pm 5.6(111-120)$ & $116-120$ & $102-123$ & 106-111 & $114-126$ & $111-124$ & $113-120$ & $115 \pm 6.6$ & $118-127$ \\
\hline Odontophore & $72.8 \pm 1.9(67-75)$ & $68-72$ & $70-84$ & $71-73$ & $69-79$ & $63-72$ & $70-75$ & $73 \pm 2.0$ & $68-74$ \\
\hline Total stylet & $186.8 \pm 6.2(182-193)$ & 184-192 & 176-207 & $178-182$ & $186-205$ & $180-195$ & 184-194 & $188 \pm 6.9$ & 186-195 \\
\hline Tail length & $35.4 \pm 2.7(31-38)$ & - & $30-44$ & $39-41$ & $28-34$ & $29-34$ & $34-38$ & $29.4 \pm 1.9$ & $24-29$ \\
\hline a.g.b & $67 \pm 4.9(61.4-93.7)$ & - & $49-102$ & - & $85-107$ & $90-113$ & 75-99 & - & $51-74$ \\
\hline a.g.b/v.d & $1.8 \pm 0.26(1.6-2.1)$ & 2.2 & $0.9-1.5$ & $1.6-2.4$ & $1.9-2.3$ & $2.2-2.9$ & $1.5-1.9$ & - & $0.8-1.1$ \\
\hline p.gb & $234 \pm 6.5(226-242)$ & & & & & & & & \\
\hline
\end{tabular}

$\mathrm{N}=$ number of specimens; $\mathrm{L}=$ body length; $\mathrm{a}=$ body length/body width; body length/distance from head to pharynx; $\mathrm{c}=$ body length/diameter at anus; $\mathrm{V}=$ distance from head to vulva/body length $\mathrm{x} 100$; $\mathrm{agb}=$ anterior genital branch; agb/vd= anterior genital branch/diameter at vulva; $\mathrm{pgb}=\mathrm{posterior}$ genital branch (All measurements in $\mu \mathrm{m}$ unless noted otherwise)

Table 2: Distribution and occurrence of Xiphinema krugi populations

\begin{tabular}{|c|c|c|c|c|}
\hline Species & Host & Local name & Origin & Reference \\
\hline X. krugi & - & natural vegetation & Piracicaba, Sao Paolo, Brazil & Lordello (1955) \\
\hline X. krugi & Vitis $\mathrm{sp}$ & grape & Garibaldi, Brazil & Oliveira et al. (2006) \\
\hline X. krugi & Eugenia uniflora & cherry & Florianopolis, Brazil & Oliveira et al. (2006) \\
\hline X. krugi & Mangifera indica & mango & Sao Jose de Rio Preto, Brazil & Oliveira et al, 2006 \\
\hline X. krugi & Cucurbita sp. & gourd & Jaranjal de Jari, Brazil & Oliveira et al. (2006) \\
\hline X. krugi & Solanum sp & potato & Concepcion, Argentina & Chaves and Mondino (2013) \\
\hline X. krugi & Allium sativum & garlic & Medanos, Argentina & Chaves and Mondino (2013) \\
\hline X. krugi & Zea mays & corn & Sadaillo, Argentina & Chaves and Mondino (2013) \\
\hline X. krugi & Fragaria sp. & strawberry & Coronda, Sta Fe, Argentina & Chaves and Mondino (2013) \\
\hline X. krugi & Solanum melongena & eggplant & Helvecia Sta Fe, Argentina & Medera (2013) \\
\hline X. krugi & Saccharum officinarum & sugarcane & Cartago, Costa Rica & Peraza-Padilla et al. (2016) \\
\hline X. krugi & Cynodon sp. & star grass & Alajuela, Costa Rica & Peraza-Padilla et al. (2016) \\
\hline X. krugi & Hevea brasiliensis & rubber & Puntarena, Costa Rica & Peraza-Padilla et al. (2016) \\
\hline X. krugi & Citrus sp. & citrus & Surinam & Loof and Maas (1972) \\
\hline X. krugi & Citrus sp. & citrus & Senegal & Luc and Hunt (1978) \\
\hline X. krugi & - & hardwood & Florida, USA & Ye and Robbins (2010) \\
\hline X. krugi & Lilium longiflorum & easter lily & Sri Lanka & Southey and Luc (1973) \\
\hline X. krugi & Ulmus parviflora & elm & Hongkong & Shen et al. (1999) \\
\hline X. krugi & - & unknown & Antioquia, Colombia & Volcy, 1990 \\
\hline X. krugi & Ceiba speciosa & silk floss & China & In present study \\
\hline
\end{tabular}

segments of 28S and ITS1 rDNA regions yielded a fragment length of approximately $840 \mathrm{bp}$ and $1227 \mathrm{bp}$, respectively. Blast homology of X. krugi (KY011942) using D2-D3 segments showed $95 \%$ similarity to closely related Xiphinema spp. available in GenBank. Meanwhile X. krugi (KY011940) showed 99\% similarity in ITS1 region to $X$. krugi populations reported by Oliveira et al. (2006).

In phylogenetic analyses of ITS1 region using Maximum Likelihood, from the Argentinean intercepted $X$. krugi by Quarantine authorities in China (KY011940) was clustered in a $(\mathrm{PP}=0.98)$ clade of $X$. krugi populations classified as genotype profile B (DQ017149-DQ017151) reported by Oliveira et al. (2006) (Fig. 3). The phylogenetic analysis using 28S region of X. krugi (KY011942) showed $\mathrm{PP}=0.83$ of similarity value to the sequences of
X. krugi from Costa Rica deposited in GenBank (KX931060) (Fig. 4).

\section{Discussion}

Morphometric heterogeneity of $X$. krugi tail varies in shape and tip structure, which is comparably and could be used as an important diagnostic character for separating populations. Luc and Hunt (1978) classified 6 populations $X$. krugi using tail characters. Tail terminus could vary from specimens having fairly long peg to specimens without peg (Coomans et al., 2001) and variation on tail shape also occurs from sub-conoid with slight bulge extremity to conoid rounded with distinct peg (Luc and Hunt, 1978). Additionally, studies carried out by Oliveira et 


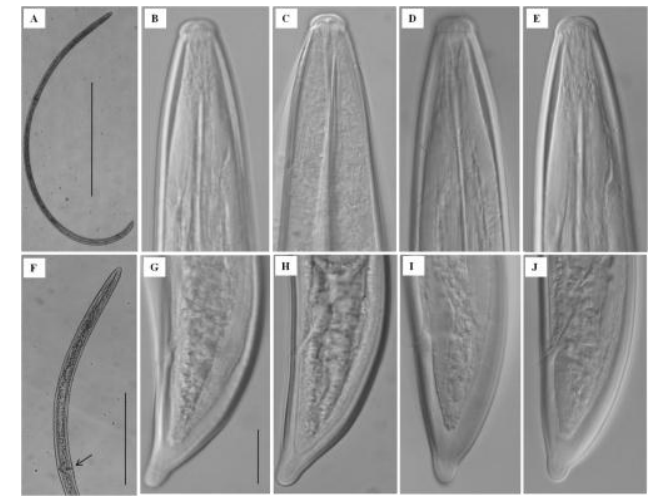

Fig. 1: Xiphinema krugi: A-C. Habitus; B-C. Head of $X$. krugi intercepted from Argentina D-E. Head of X. krugi from USA; F. Position of vulva from anterior; G-H. Tail of $X$. krugi intercepted from Argentina; I-J. Tail of $X$. krugi USA (Scale bars: A=100 $\mu \mathrm{m} ; \mathrm{F}=50 \mu \mathrm{m}$; B-E, G-J= $10 \mu \mathrm{m}$ )

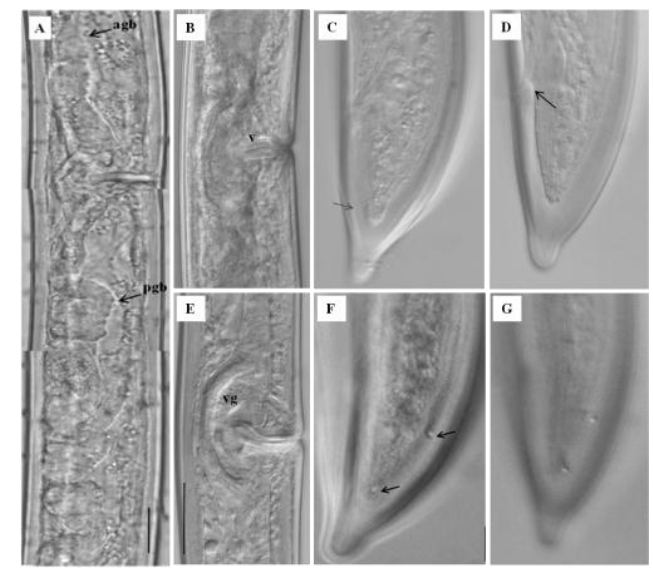

Fig. 2: Xiphinema krugi: A. Reproductive system of $X$. krugi intercept from Argentina showing reduced anterior genital branch (agb) and normal development of posterior genital branch (pgb); B, E. vulva and vaginal orientation of $X$. krugi intercept from Argentina; C. faint oblique lines in tail terminus; D. anus position; F. Position of tail papillae in $X$. krugi intercept from Argentina; G. Tail papillae in $X$. krugi USA (Scale bar: A=5 $\mu \mathrm{m} ; \mathrm{B}-\mathrm{G}=10 \mu \mathrm{m}$ )

al. (2006) clearly separated X. krugi populations into four distinct groups or morphospecies based on principal component analysis (PCA) of morphometric characters and four distinct genotype profiles using the ITS1 region (Type A-D).

Morphometric characters in our study agreed with the morphometric characters previously reported by Chaves and Mondino (2013) for X. krugi populations from Argentina, and from Brazilian studies of $X$. krugi population reported by Oliveira et al. (2006). Our studies showed very slight variations in morphometric values of c' ratio (1.1 vs. 1.3 vs. $1.2 \mu \mathrm{m}$ ), odontostyle length (114 vs. 112 vs. $116 \mu \mathrm{m}$ ), ratio of anterior genital branch as expressed to diameter of vulva

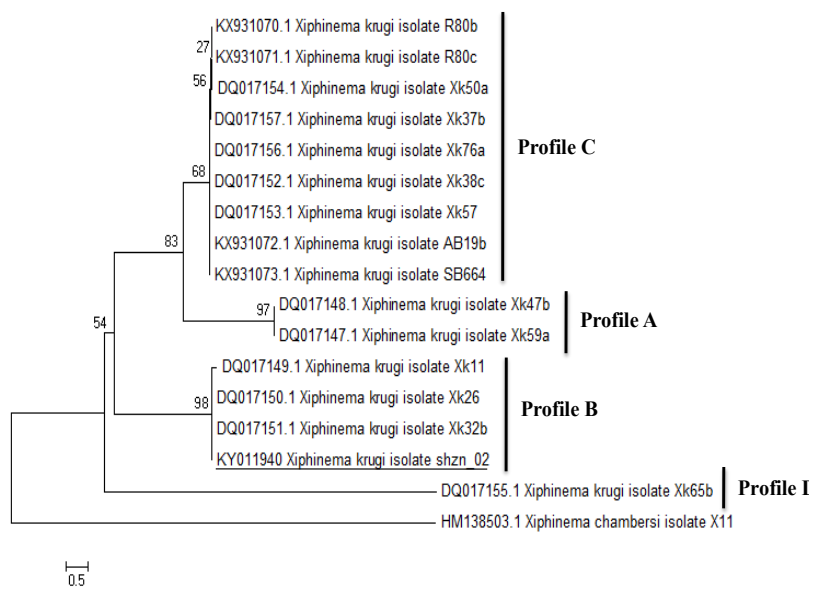

Fig. 3: Maximum likelihood tree showing relationships of $X$. krugi population based on ITS1 region. Sequence data sets of X. krugi populations reported by Oliveira et al. (2006) were used to construct the tree. The percentage of replicate trees in which the associated taxa clustered together in the bootstrap tests (1000 replicates) and is shown above the branches

\section{(1.8 vs. 1.6 vs. $2.2 \mu \mathrm{m})$.}

Based from Luc and Hunt (1978) classification of $X$. krugi tail character, the $X$. krugi intercepted in China is most similar to category 12 (Florida tail), a tail of conoid shape with rounded terminus and a distinct ventral peg at tail extremity. Additionally, the morphometric of intercepted population agreed well on the morphometric characters of X. krugi population PX32b from Brazil which falls in the category of morphospecies type B as classified by Oliveira et al. (2006).

Molecular analysis of $X$. krugi intercepted population showed homologies to putative populations of $X$. krugi Brazil and X. krugi Costa Rica but phylogenetic relationship only revealed a well-supported clade $(\mathrm{PP}=0.98)$ to $X$. krugi genotypes profile B (DQ017149-DQ017151) of Brazilian putative species, while comparatively different to $X$. krugi Costa Rica (KX931072-KX931073) from which the latter was clustered to profile $\mathrm{C}$ (Fig. 3). The genotypic difference between the $X$. krugi intercept in China and recently described X. krugi from Costa Rica is explained from dissimilarity of tail shape of Costa Rican population having a sub-conoid tail with a slight bulge at the extremity but never considered a peg. In contrast, further interpretation and comparison of phylogenetic relationship of $28 \mathrm{~S}$ region cannot be clearly interpreted due to very few $X$. krugi $28 \mathrm{~S}$ sequence deposited in the GenBank.

Delineation of $X$. krugi using morphology and sequence data were addressed in this study to consider studying intra-population variability in the future. Oliveira et al. (2006) and Peraza-Padilla et al. (2016) agreed that $X$. krugi is a possible complex species because of diversity of tail characters between populations. The wide difference of 


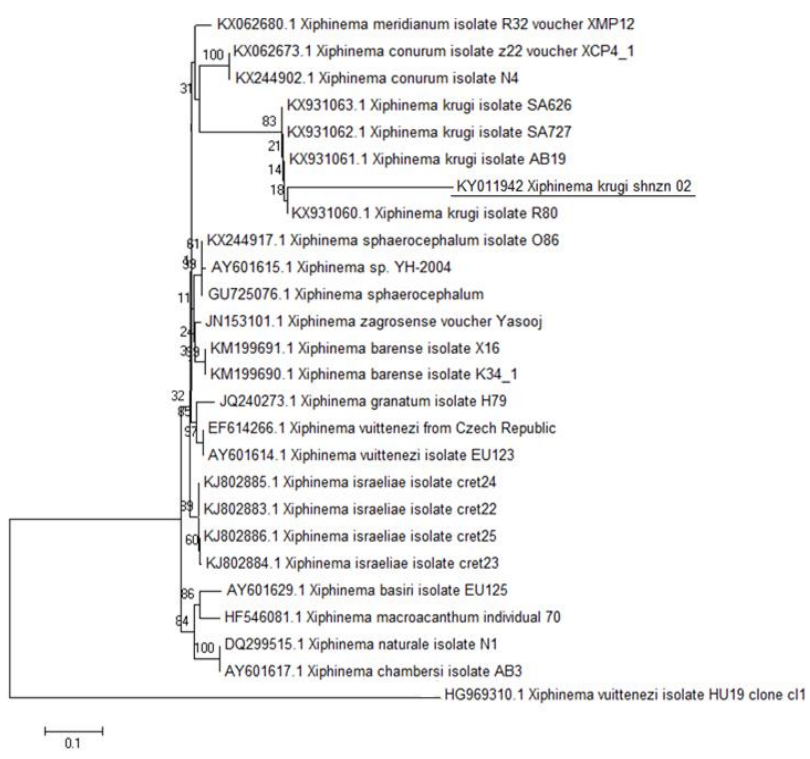

Fig. 4: Phylogenetic relationships of $X$. krugi population as inferred from partial D2-D3 expansion segments with comparison of Xiphinema spp. The percentage of replicate trees in which the associated taxa clustered together in the bootstrap test (1000 replicates) is shown above the branches

tail shape may be due to geographical intraspecific variability and may possibly comprise cryptic species with distance genotypes. Recent description of $X$. krugi from Costa Rica and $X$. krugi intercepted in China is one of a conclusive evidence of intra-species variability among $X$. krugi populations.

In conclusion, a study of different populations is essential to clarify this species complex. It is also necessary to consider in future studies providing a mitochondrial DNA sequence $(C O I)$ which may offer a more accurate confirmation of $X$. krugi status. This is the first interception report of $X$. krugi from Argentina in China associated with a possible host Ceiba speciosa.

\section{Acknowledgements}

This research was supported by the National Natural Science Foundation of China (No. 31371921). The authors wish to acknowledge Dr. Weimin YE for providing specimens of $X$. krugi from USA for morphological comparison.

\section{References}

Bala, G., 1984. Occurrence of plant-parasitic nematode associated with crops of agricultural importance in Trinidad. Nematropica, 14: 37-45

Brown, D.J.F. and B. Boag, 1988. An examination of methods used to extract virus-vector nematodes from soil samples. Nematol. Mediterr., 16 93-99

Chaves, E.J. andE.A. Mondino, 2013. Description of some Xiphinema species populations (Nematoda) from Argentina. Nematropica, 43: 68-77
Coomans, A., R. Huys, J. Heyns and M. Luc, 2001. Character analysis, phylogeny, and biogeography of the genus Xiphinema Cobb, 1973 (Nematoda, Longidoridae). Ann. Mus. Roy. Afr. Centr., 2: 87-99

Costa Manso, E.S., B.G. Tenente, R.C.V. Ferraz, L.C.C.B. Oliveira and R. Mesquita, 1994. Catalogue of phytoparasitic Nematodes Found Associated with Different Types of Plants in Brazil, pp: 443-488. Brasília, DF, Brazil, Ministério da Agricultura

Crozzoli, R., F. Lamberti, N. Greco and D. Rivas, 2001. Plant parasitic nematode associated with cocoa in Choroni, Cumboto and Cuyagua, Aragua State. Fitophatol. Ven., 14: 5-12

Decraemer, W., M.E. Doucet and A. Coomans, 1998. Longidoridae from Argentina with description of Paraxiphidorus brevistylus sp. $\mathrm{n}$. (Nematoda: Longidoridae). Fund. Appl. Nematol., 21: 371-388

De Ley, P., M.A. Felix, L.M. Frisse, S.A Nadler, P.W. Sternberg and W.K. Thomas, 1999. Molecular and morphological characterization of two reproductively isolated species with mirror-image anatomy (Nematoda:Cephalobidae). Nematology, 1: 591-612

Doucet, M.E., L.C.C.B. Ferraz, J.C. Magunacelaya and D.J.F. Brown, 1998 The occurrence and distribution of Longidorid nematodes in Latin America. Russ. J. Nematol., 6: 111-128

Germani, G., 1989. Description of Xiphinema guillaumeti sp. n. (Nematoda: Longidoridae) and measurements on six other species of Xiphinema from Brazilian Amazonia. Nematologica, 35: 69-75

Gutierrez, C., J.E. Palomares-Rius, C.Cantalapiedra-Navarrete, B.B. Landa and P. Castillo, 2010. Prevalence, polyphasic identification and molecular phylogeny of dagger and needle nematodes infesting vineyards in Southern Spain. Eur. J. Plant Pathol., 129: 427-453

Jacob, J.J. and P.A.A. Loof, 1996. Some plant-parasitic nematodes from Uruguay, with description of Neodolichodorus citri. Nematologica, 14: $275-281$

Lamberti, F., R. Roca, R.D. Sharma, J.P. Pimentel, A. Agostinelli, H. Antonio and R.R.A. Lordello, 1978. On the occurrence of Xiphinema species in Brazil. Nematol. Bras., 11: 287-291

Loof, P.A.A. and P.W. Maas, 1972. The genus Xiphinema (Dorylaimida) in Surinam. Nematologica, 18: 92-110

Lordello, L.G.E., 1955. Xiphinema krugi n.sp. (Nematoda: Dorylaimidae) from Brazil with key to the species of Xiphinema. Helminthol. Soc. Proc., 22: 16-21

Luc, M. and D. J. Hunt, 1978. Redescription of Xiphinema longicaudatum Luc, 1961 and observations on X. krugi Lordello, 1955 (Nematoda: Longidoridae). Nematologica, 24: 1-18

Luc,M. and A. Coomans, 1992. Phytoparasitic nematodes of genus Xiphinema (Longidoridae) in Guyana and Martinique. Belg. J. Zool., 122: 147183

Luc, M. and M.E. Doucet, 1990. The family Longidoridae Thorne, 1935 (Nemata) in Argentina. Distr. Rev. Cienc. Agrop., 7: 19-25

Medera, C., 2013. Observations on Plant parasitic nematodes from Argentina. Rev Argent de Nematol., 4: 36-42

Maximiano, C., T.G. Silva, C.R. Souza, E.A. Ferreira, A.F Pereira, G.E. Pereira, M.A. Regina and V.P. Campos, 1998. Nematodes and Pasteuria spp. in association with temperate fruits trees in the South Minas Gerais State, Brazil. Nematol. Bras., 23: 1-10

Oliveira, C. M., J. Hubschen, D.J. Brown, L.C.C. Ferraz, F. Wright and R. Neilson, 2004. Phylogenetic relationships among Xiphinema and Xiphidorus nematode species from Brazil inferred from 18S rDNA sequences. J. Nematol., 36: 153-159

Oliveira, C.M.G., C.C.B. Ferraz and R. Neilson, 2006. Xiphinema krugi, species complex or cryptic species. J. Nematol., 38: 418-428

Peraza-Padilla, W., A. Archidone-Yuste, H. Ferris, T. Zamora-Araya, C. Cantalapiedra-Navarrete, J.E. Palomares-Rius, S.A. Subottin and P Castillo, 2016. Molecular characterization of pseudomonodelphic dagger nematodes of Xiphinema Cobb, 1913 (Nematoda:Longidoridae) in Costa Rica, with notes on Xiphinema setariae Tarjan, 1964. Eur. J. Plant Pathol., 148: 739-747

Ye, W., A.L. Szalanski and R.T. Robbins, 2004. Phylogenetic relationship and genetic variation in Longidorus and Xiphinema species (Nematoda: Longidoridae) using ITS sequences of nuclear ribosomal DNA. $J$ Nematol., 36: 14-19

Taylor, C.E. and D.J.F. Brown, 1997. Nematode Vectors of Plant Viruses Wallingford, UK: CAB International Tervuren, Belgique 
Barsalote et al. / Int. J. Agric. Biol., Vol. 19, No. 5, 2017

Shen, P., Z. Gu and H. Li, 1999. Xiphinema krugi found in china associated with import potted landscape. Plant Quarantine, 13: 70-73

Southey, J.F. and M. Luc, 1973. Redescription of Xiphinema ensiculiferum (Cobb, 1893) Thorne 1937 and description of Xiphinema loosi n. sp. and Xiphinema hygrophilum n.sp. (Nematoda : Dorylaimoidea) Nematologica, 19: 293-307

Tamura, K., D. Peterson, N. Peterson, G. Stecher, M. Nei and S. Kumar, 2011. MEGA 5: Molecular Evolutionary Genetics Analysis using maximum likelihood, evolutionary distance, and maximum parsimony methods. Mol. Biol. Evol., DOI: 10.1093/molbevmsr121
Thompson, J.D. D.G. Higgins and T.J. Gibson, 1994. CLUSTAL W: improving the sensitivity of progressive multiple sequence alignment through sequence weighting, position specific gap penalties and weight matrix choice. Nucleic Acids Res., 22: 4673-4680.

Volcy, C., 1990. Presence of Xiphinema krugi in Antioquia, Colombia and observation on its variable morphology. Phytopathol Col., 14: 18-23

Ye, W. and R. Robbins, 2010. Morphological comparison of Xiphinema krugi from Arkansas, Hawaii and North Carolina. J Nematol., 42: 266-268

(Received 24 January 2017; Accepted 26 May 2017) 